\title{
Chapter 45 \\ Advanced Pathology Techniques for Detecting Emerging Infectious Disease Pathogens
}

\author{
Wun-Ju Shieh and Sherif R. Zaki
}

\section{Introduction}

Detection and surveillance for emerging and reemerging pathogens need a multidisciplinary approach. The intertwining complexity of these pathogens with their diverse tissue tropisms, direct effects on host cells, multiphasic immunological responses, and additional influence of superimposed secondary agents is beyond the expertise of a single discipline in modern medicine. A combined evaluation of patient's history, clinical manifestations, and physical examination may suggest a list of differential diagnosis, but it is often insufficient to determine the specific infectious etiology. Laboratory methods are essential to identify an etiologic agent from testing clinical samples, such as blood, serum, nasopharyngeal swab, etc. These methods, including traditional microbiological techniques, conventional immunological assays, and modern molecular methods, remain the mainstay in today's practice of clinical microbiology and infectious disease medicine. Nevertheless, there are technical and logistic issues associated with these methods, and the test results often lack a clinicopathologic correlation that can confound the interpretation of their clinical significance. For example, microbiological culture may fail to grow a causative organism, while the organism isolated by the laboratory in vitro may arise from contamination and does not represent the actual infective agent in vivo.

Pathology plays a key role as a bridging subspecialty in such multidisciplinary approach. Pathologic examination, if available, can establish a more specific diagnosis correlated with clinical manifestations. Although general practice of pathology

\footnotetext{
W.-J. Shieh $(\bowtie) \cdot$ S.R. Zaki

Infectious Diseases Pathology Branch, Division of High-Consequence Pathogens \& Pathology, National Center for Emerging and Zoonotic Infectious Diseases, Centers for Disease Control and Prevention, 1600 Clifton Road, N.E., Mail Stop G-32, Atlanta, GA 30333, USA e-mail: wshieh@cdc.gov
} 
Table 45.1 Examples of outbreaks caused by emerging pathogens initially identified or confirmed by pathologic studies

\begin{tabular}{lll}
\hline Year(s) & Disease outbreak & Country or geopolitical region \\
\hline 1993 & Hantavirus pulmonary syndrome & USA \\
1995 & Ebola hemorrhagic fever & Zaire \\
1995 & $\begin{array}{l}\text { Leptospirosis associated with pulmonary } \\
\text { hemorrhage }\end{array}$ & Nicaragua \\
& Lassa hemorrhagic fever & Sierra Leone \\
1996 & Enterovirus 71 hand-foot-and-mouth disease & Malaysia \\
1997 & $\quad$ with encephalitis \\
& H5N1 influenza & \\
1997 & Enterovirus 71 hand-foot-and mouth disease & Hong Kong \\
1998 & $\quad$ with encephalitis & \\
& Nipah virus encephalitis \\
1999 & West Nile encephalitis & Malaysia \\
1999 & Rift Valley fever & USA \\
2000 & Ebola hemorrhagic fever & Saudi Arabia/Yemen \\
2000 & Inhalational and cutaneous anthrax & Uganda \\
2001 & Transplant-associated West Nile encephalitis & USA \\
2002 & Sever acute respiratory syndrome & USA \\
2003 & Monkeypox & USA \\
2003 & Transplant-associated lymphocytic & USA \\
2003,2005, & $\quad$ choriomeningitis virus & \\
2007,2010 & Transplant-associated rabies & USA \\
2004 & Rift Valley fever & Kenya/Somalia \\
$2006 / 2007$ & Lujo virus hemorrhagic fever & Zambia/South Africa \\
2008 & H1N1 pandemic influenza & Global \\
2009 & Transplant-associated Balamuthia mandrillaris & USA \\
2009 & Dengue hemorrhagic fever & Puerto Rico \\
2010 & Leptospirosis & Puerto Rico \\
2011 & &
\end{tabular}

is largely oriented toward diagnosis of neoplastic diseases, pathologists have been increasingly called upon to make diagnoses from tissue samples collected by cytology, biopsy, and autopsy procedures in response to the challenge of emerging infections [1-4]. Using these tissue samples as the source for laboratory workup, pathologists have made various contributions to our understanding of emerging infectious diseases in diagnostics, pathogenesis, epidemiology, and clinical aspects of these diseases (Table 45.1). In addition, results from pathologic studies can help design better strategies for control and prevention of these emerging infectious diseases, especially when they occur as an outbreak [5, 6]. Furthermore, pathologic studies also play an essential role in identifying the effects of secondary pathogens that commonly complicate the primary disease syndrome [7, 8].

Recent advances in molecular biology have revolutionized the practice of medicine, especially in the arena of diagnostic pathology and laboratory medicine [9-11]. The practice of pathology has evolved from using morphologic pattern 
recognition as the main tool to a sophisticated medical subspecialty by applying a wide array of advanced immunologic and molecular techniques on top of the traditional methods. The so-called "traditional methods" include routine hematoxylin and eosin (H\&E) stain, histochemical (special) stain, and electron microscopy (EM). The more commonly used advanced techniques include immunohistochemistry (IHC), in situ hybridization (ISH), polymerase chain reaction assay (PCR), and tissue microarrays. Other advanced techniques that are less standardized as diagnostic utilities include confocal microscopy, proteomics, laser capture microdissection (LCM), and in situ PCR. The results from these techniques provide different information regarding the infectious agents in the organ systems they involve (Table 45.2). Each technique has its respective advantages and limitations, and there is no single technique that can stand alone as the only method for etiologic diagnosis. The advanced techniques complement the traditional methods to confirm the diagnosis; therefore, it is always necessary to apply these techniques as an integrated laboratory utility to take full advantage of the pathology approach. A good example to illustrate such approach is the identification of a novel coronavirus during the global epidemic of severe acute respiratory syndrome (SARS) in 2003 [12-17]. By using traditional culture (Fig. 45.1a) and EM examinations (Fig. 45.1b) on clinical samples and tissue specimens, the morphologic evidence of coronavirus leads to subsequent anatomic localization of this novel virus in lung tissues by using a combination of IHC (Fig. 45.1c), ISH (Fig. 45.1d), and PCR. Ultimately, correlations of these data with serological and clinical findings confirmed the SARS-associated coronavirus (SARS-CoV) as the etiologic pathogen of the outbreak. This is a prime example of the contributions made by infectious disease pathology as part of a multidisciplinary approach to investigate emerging infections and disease outbreaks.

Table 45.2 Pathology techniques and their utilities for infectious disease diagnosis

\begin{tabular}{|c|c|c|}
\hline Technique & Main utility & Remarks \\
\hline $\begin{array}{l}\text { Hematoxylin \& Eosin } \\
\text { Stain (H\&E) }\end{array}$ & $\begin{array}{l}\text { Shows histopatho- } \\
\text { logic features of } \\
\text { infectious } \\
\text { process }\end{array}$ & $\begin{array}{l}\text { * Illustrates the evidence of a microbial infection } \\
\text { and provides guidance to subsequent } \\
\text { laboratory testing } \\
\text { * Does not highlight the pathogen per se } \\
\text { * Can only suggest certain infections and not a } \\
\text { specific etiologic organism }\end{array}$ \\
\hline $\begin{array}{l}\text { Histochemical stain } \\
\text { (special stain) }\end{array}$ & $\begin{array}{l}\text { Highlights } \\
\text { organisms }\end{array}$ & $\begin{array}{l}\text { * More useful for bacterial, mycobacterial, and } \\
\text { fungal organisms } \\
* \text { Only categorizes organisms within a broad } \\
\text { classification but not a specific species } \\
* \text { Can be difficult to interpret }\end{array}$ \\
\hline $\begin{array}{l}\text { Electron microscopy } \\
\quad(\mathrm{EM})\end{array}$ & $\begin{array}{c}\text { Illustrates microbial } \\
\text { ultrastructure }\end{array}$ & $\begin{array}{l}* \text { The most direct evidence to show an infectious } \\
\text { agent } \\
* \text { Time consuming and limited to small areas of } \\
\text { interest }\end{array}$ \\
\hline
\end{tabular}


Table 45.2 (continued)

\begin{tabular}{|c|c|c|}
\hline Technique & Main utility & Remarks \\
\hline $\begin{array}{l}\text { Immunohistochemistry } \\
\text { (IHC) }\end{array}$ & $\begin{array}{l}\text { Localizes microbial } \\
\text { antigens }\end{array}$ & $\begin{array}{l}\text { * Demonstrates antigens regardless the organism } \\
\text { is intact or not } \\
* \text { Provides histomorphologic correlation of } \\
\text { infectious process } \\
\text { * Many commercially available antibodies for } \\
\text { common pathogens } \\
\text { * Antibodies of novel pathogens may not be } \\
\text { readily available } \\
\text { * Formalin fixation may decrease sensitivity }\end{array}$ \\
\hline $\begin{array}{l}\text { In situ hybridization } \\
\text { (ISH) }\end{array}$ & $\begin{array}{l}\text { Localizes microbial } \\
\text { nucleic acids }\end{array}$ & $\begin{array}{l}\text { * Probes can be synthesized in-house with known } \\
\text { sequence } \\
* \text { Provides histomorphologic correlation of } \\
\text { infectious process } \\
* \text { Usually more specific but less sensitive than } \\
\text { IHC } \\
\text { * Formalin fixation may decrease sensitivity }\end{array}$ \\
\hline $\begin{array}{l}\text { Polymerase chain } \\
\text { reaction assay } \\
\quad(\mathrm{PCR})\end{array}$ & $\begin{array}{l}\text { Amplifies small } \\
\text { amount of } \\
\text { microbial } \\
\text { nucleic acids }\end{array}$ & $\begin{array}{l}* \text { Usually more sensitive than IHC and ISH } \\
* \text { Contamination issues frequently encountered } \\
* \text { Does not provide histomorphologic correlation } \\
\text { of infectious process } \\
* \text { Formalin fixation may decrease sensitivity }\end{array}$ \\
\hline Tissue microarray & $\begin{array}{l}\text { Detects multiple } \\
\text { microbial } \\
\text { nucleic acids }\end{array}$ & $\begin{array}{l}* \text { Facilitate sequence analysis and pathogen } \\
\text { identification } \\
* \text { Can detect microbes and assess related host } \\
\text { responses simultaneously } \\
* \text { Biosafety concerns using frozen tissues } \\
* \text { Less sensitive than conventional PCR }\end{array}$ \\
\hline Confocal microscopy & $\begin{array}{l}\text { Increases morpho- } \\
\text { logic dimension }\end{array}$ & $\begin{array}{l}\text { * Provides wider spectrum for histopathologic or } \\
\text { cytologic interpretation } \\
* \text { Limited diagnostic utility for emerging } \\
\text { pathogens }\end{array}$ \\
\hline $\begin{array}{l}\text { Laser capture } \\
\text { microdissection } \\
(\mathrm{LCM})\end{array}$ & $\begin{array}{l}\text { Dissect specific } \\
\text { target cells for } \\
\text { PCR or } \\
\text { proteomic } \\
\text { studies }\end{array}$ & $\begin{array}{l}\text { * Useful in studies of pathogenesis } \\
\text { * Limited diagnostic utility for emerging } \\
\text { pathogens }\end{array}$ \\
\hline $\begin{array}{l}\text { In situ polymerase } \\
\text { chain reaction assay }\end{array}$ & $\begin{array}{l}\text { Localizes microbial } \\
\text { nucleic acids } \\
\text { with } \\
\text { amplification } \\
\text { process }\end{array}$ & $\begin{array}{l}* \text { Combines amplification and in situ localization } \\
\text { methods } \\
* \text { Inherent technical issues with nonstandardized } \\
\text { protocols } \\
* \text { Formalin fixation may decrease sensitivity } \\
* \text { Limited diagnostic utility for emerging } \\
\text { pathogens }\end{array}$ \\
\hline Proteomics & $\begin{array}{l}\text { Detects microbial } \\
\text { and host } \\
\text { peptides }\end{array}$ & $\begin{array}{l}* \text { Useful in studies of pathogenesis } \\
* \text { Formalin fixation may decrease sensitivity } \\
* \text { Limited diagnostic utility for emerging } \\
\text { pathogens }\end{array}$ \\
\hline
\end{tabular}



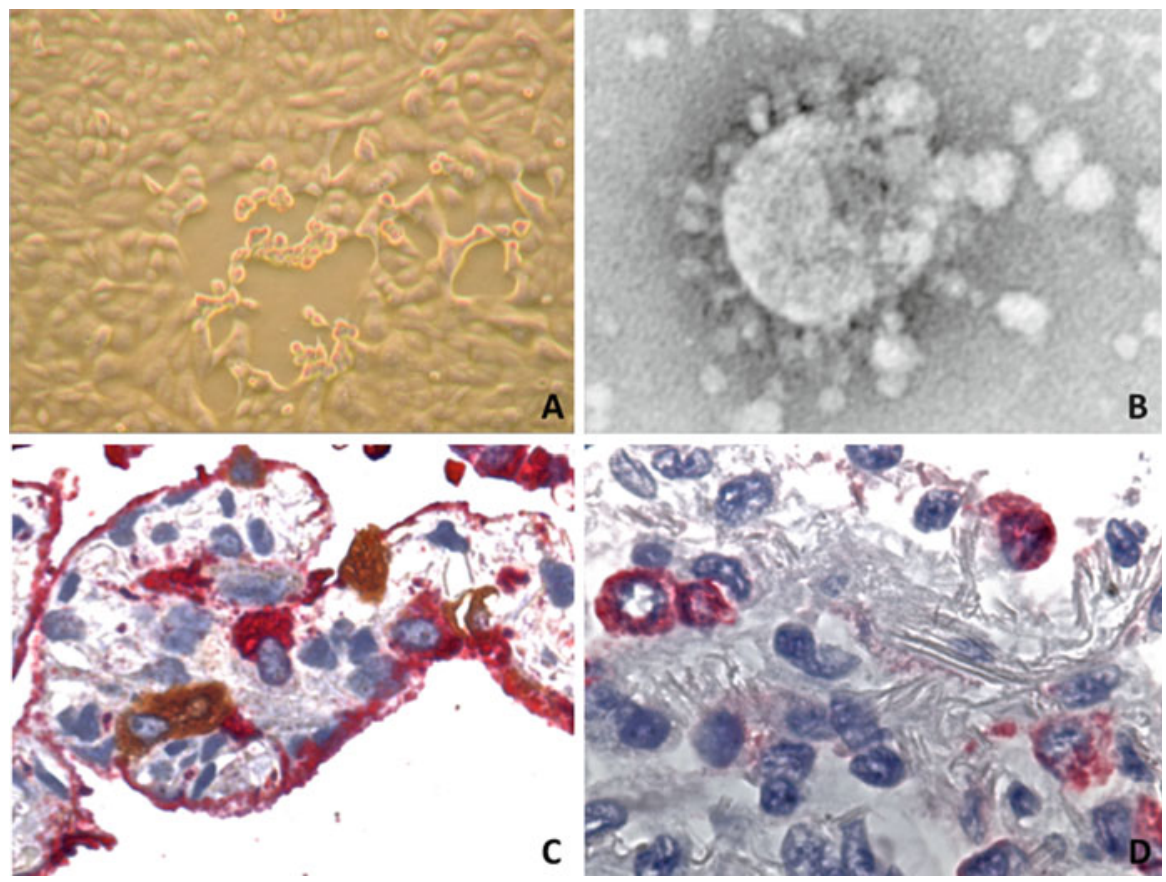

Fig. 45.1 (a) Vero E6 cells show early cytopathic effect with coronavirus isolates from patients with SARS. (Courtesy of Dr. Thomas G. Ksiazek). (b) Negative stain (methylamine tungstate stain) electron microscopy shows coronavirus particle with an internal helical nucleocapsid-like structure and club-shaped surface projections. (Courtesy of Dr. Charles D. Humphrey). (c) Doublestain IHC (immunoalkaline phosphatase polymer and peroxidase polymer) shows SARS-CoV (red) and surfactant antigens (brown) in type II pneumocytes. (d) ISH shows SARS-CoV nucleic acids in pneumocytes

\section{Highlights of Techniques}

\section{Hematoxylin \& Eosin Stain}

Any pathology laboratory dealing with clinical diagnosis routinely performs $H \& E$ stain. It demonstrates the histologic and cytologic features in a tissue section and allows the pathologists to examine the microscopic changes related to infectious processes. This is the most unequivocal method to illustrate the evidence of a microbial infection and its consequence in the tissue. For example, the presence of abundant neutrophils in pulmonary alveoli is indicative of pneumonia (Fig. 45.2a), while neutrophils in meninges support the diagnosis of meningitis. However, these histopathologic findings shown by H\&E stain are not specific because they can be caused by a variety of organisms; their importance is to pave the first step leading to further laboratory assays for detecting the causative agent. 


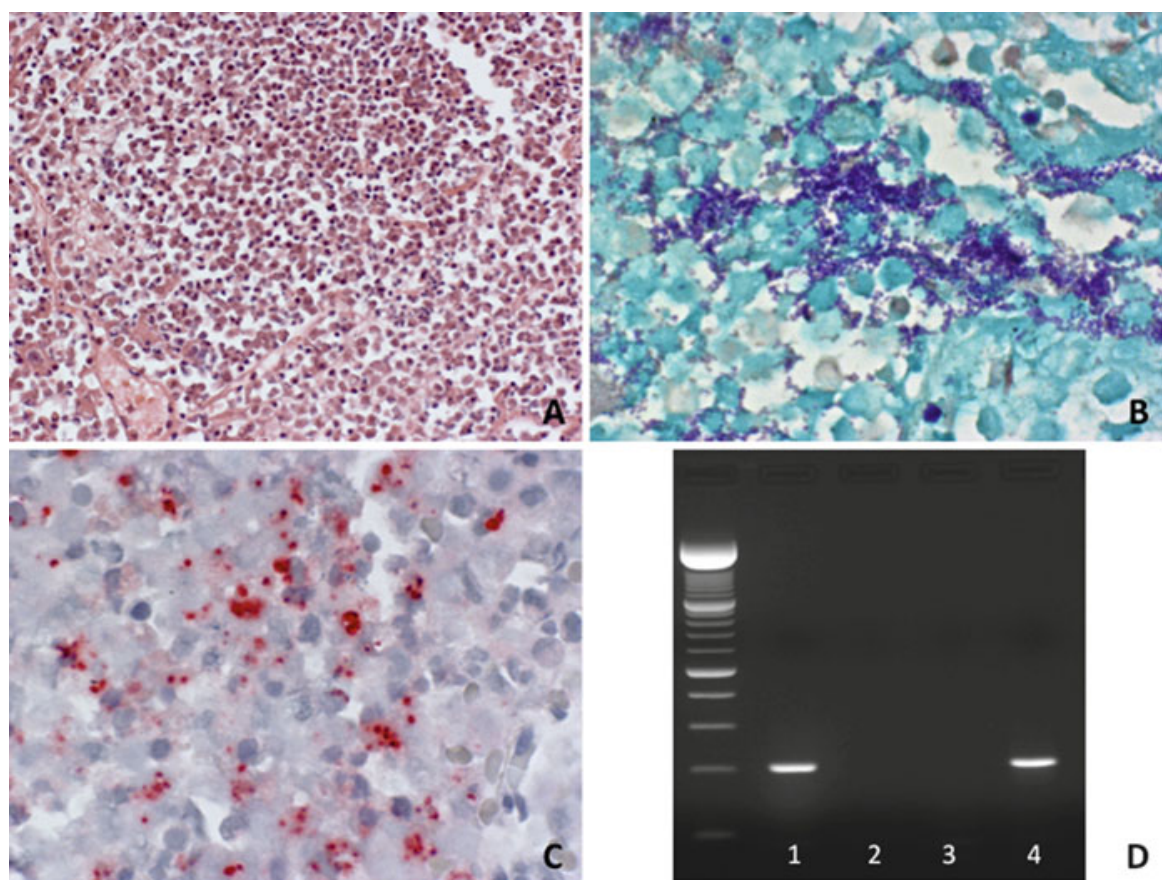

Fig. 45.2 (a) H\&E stain shows abundant polymorphonuclear inflammatory cells in alveoli indicative of an acute pneumonia. (b) Gram stain highlights numerous gram-positive cocci mixed with inflammatory cells. (c) IHC with anti-S. pneumoniae antibody shows abundant extracellular and intracellular bacterial antigens. (d) PCR targeting pneumolysin gene of S. pneumonia shows positive amplicon. (lane 1: positive control; lane 2: negative control; lane 3: water control; lane 4: lung sample tested)

\section{Histochemical Stains (Special Stains)}

Many histochemical stains have been developed to highlight a variety of microbial organisms. Some of the common ones are tissue Gram stain (for bacteria), Grocott's methenamine silver stain (for fungi), acid-fast stain (for mycobacteria), periodic acid-Schiff stain (for organisms with high content of carbohydrate macromolecules), Warthin-Starry silver stain or Steiner's silver stain (for spirochetes and other bacteria). Interpretation of these special stains performed on tissue sections is usually more difficult than those performed on cultures because the coexistence of host tissue responses and accompanied histopathologic changes in the sections can confound the interpretation. It needs more expertise and effort to examine these special stains and usually requires a trained pathologist to carry out such examination. For example, Streptococcus pneumoniae can appear as gram-negative cocci in tissue sections because the host inflammatory responses, antibiotic treatment, or autolysin produced by the bacteria per se can damage the bacterial cell wall and render the 
Gram stain appear negative. Even when these special stains properly highlight organisms of interest, they can only categorize them within a broad classification but not a specific species. For example, gram-positive cocci demonstrated by tissue Gram stain in a lung section (Fig. 45.2b) could represent different species of Streptococci or Staphylococci, and further testing with more specific assays is needed to reveal the true identity of these cocci.

\section{Electron Microscopy}

Four decades ago, EM was the only ancillary technique available to the pathologists when routine $\mathrm{H} \& \mathrm{E}$ and special stains failed to reveal diagnostic features in histopathology [18]. EM examination provides a direct visualization of microbial organisms at a high magnification. Ultrastructural finding is the most direct evidence to show the presence of an infectious agent in clinical specimens. Thin section and negative stain are two common EM methods used to study pathogen morphology and morphogenesis of the microorganisms with recognition of their cytoplasmic organelles and matrix constituents. Therefore, correlation of light and electron microscopic findings not only improves pathologist's diagnostic acumen but also allows for a more coherent explanation of the pathogenesis. Since the advent of immunohistochemical and molecular techniques, EM has been less often used for identifying infectious agents. However, EM still played an essential role in determining the specific family of the pathogen involved in several outbreaks caused by novel viruses, such as Sin Nombre virus [19, 20], Nipah virus [21, 22], SARS-CoV [12, 23], and monkeypox virus [24]. In these outbreak investigations, negative stain of virus isolated from tissue culture and thin-section preparation of tissue specimen facilitated the ultrastructural examination. The determination of etiologic agents guided subsequent laboratory, clinical, and epidemiologic investigations. Advanced EM methods, such as immuno-EM or EM in situ hybridization using colloidal gold labels, have been developed for a more specific ultrastructural diagnosis.

\section{Immunohistochemistry}

IHC has been widely used in all aspects of pathology diagnosis in the past three decades [25-27]. A large number of IHC is available that can be helpful in the identification of microorganisms. By using a variety of antibodies, IHC can detect the presence of microbial antigens in tissue specimens, whether they represent the intact or degraded pathogens, and whether they are intracellular or extracellular (Fig. 45.2c). Therefore, IHC has become a powerful technique used by pathologists for tissue diagnosis of infectious diseases. There are many ways to visualize an antibody-antigen interaction. The most common method is to apply an antibody conjugated to an enzyme, such as peroxidase [28-30] or alkaline 
phosphatase [31, 32], which can further catalyze a reaction for colorimetric detection. The antibodies used for specific detection can be polyclonal or monoclonal. Polyclonal antibodies are a heterogeneous mixture of antibodies that recognize several epitopes of a specific organism or more commonly, a group of related organisms. Monoclonal antibodies are generated against a single epitope and hence more specific to the target antigen than polyclonal antibodies. Many of these antibodies are commercially available and are widely used in diagnostic pathology laboratories. Others, especially those antibodies for detecting novel emerging pathogens, are available only at highly specialized centers such as the Centers for Disease Control and Prevention. Development of new IHC is a worthwhile but usually labor-intensive task. Similar to all other laboratory assays, the sensitivity and specificity of any IHC always need a careful evaluation before establishing its status as a diagnostic assay.

Detection of two or more target antigens on one slide can be achieved with multiple staining IHC assays [33-35]. These assays can expand the information obtained from each slide and reduce turnaround-time compared to single staining or sequential staining methods. It is possible to assess the topographic relationship of the targets by using multiple staining IHC assays for determining the cellular tropism of viral infection with antibodies raised against virus and specific cellular markers respectively (Fig. 45.1c). These multiple staining methods not only help confirm the immunolocalization of pathogens but also enhance further understanding of pathogenesis in many emerging infections [7, 16, 19].

There are many advantages of using formalin-fixed tissues and IHC to detect etiologic pathogens. It is particular useful in detecting those fastidious or slowgrowing organisms, such as mycobacteria [36, 37] or Tropheryma whipplei [38], and can improve the speed, sensitivity, and specificity of microbial diagnosis. It is also valuable for characterizing emerging infections, whose causes are initially unknown, such as those caused by Nipah virus [21] or SARS-CoV [12]. Immunolocalization of antigens by IHC provides histomorphologic correlation between the infectious pathogen and host tissue responses, which is not only crucial for diagnosis but also important to study the pathogenesis of those emerging infections [19, 21, 39, 40]. Additionally, IHC performed on fixed tissues can minimize laboratory worker's potential risk of exposure to infectious agents because of the deactivation of pathogens by formalin fixation. Another advantage of using IHC is its capability of detecting well-preserved microbial antigens in archived formalin-fixed, paraffin-embedded (FFPE) tissues, which allows retrospective studies of many emerging pathogens even after decades of archive [41, 42].

\section{In Situ Hybridization}

ISH is a technique that uses fluorescent or radiolabeled nucleic acid probes comprising complementary DNA or RNA strand to localize specific sequences in tissue sections $[43,44]$. It has been applied in many medical diagnostics, such as gene 
expression profiling, chromosomal integrity, and karyotyping, etc. There are also many ways to perform ISH in diagnosis of infectious pathogens with a variety of probes [45-50], including double-stranded DNA (dsDNA) probes, single-stranded DNA (ssDNA) probes, RNA probes (riboprobes), and synthetic oligonucleotides (oligoprobes). ISH can localize nucleic acids of microorganisms in tissues and provides histomorphologic correlation between the infectious pathogen and host tissue responses, similar to IHC. The advantages of using formalin-fixed tissues and ISH to detect etiologic pathogens are also similar to IHC, except it is usually less sensitive than IHC because of the potential fragmentation of target nucleic acids by formalin fixation $[51,52]$. On the other hand, ISH can utilize in-house probes synthesized in a well-equipped laboratory with known sequences of the target nucleic acids, minimizing the need to depend on commercial resources.

\section{Polymerase Chain Reaction Assay}

PCR amplification undoubtedly is the most sensitive method available to detect microbial organisms in tissue specimens and has become a common practice in many pathology laboratories. PCR can be performed on FFPE samples [53-56]; therefore diagnoses can be made even if cultures were not obtained initially from biopsy or autopsy at the time of processing. In addition, molecular identification can accelerate definitive diagnosis of fastidious organisms that either grow slowly or does not grow at all with culture methods. When combined with other techniques mentioned above, PCR has markedly improved the capabilities of providing rapid and accurate detection of many emerging and reemerging pathogens as well as pathogens commonly encountered in medical practice.

PCR requires the isolation of nucleic acids from microorganisms in clinical samples and needs to apply adjunct techniques with restriction endonuclease enzymes, gel electrophoresis (Fig. 45.2d), and other nucleic acid hybridization methods. Degenerate primers can be employed in PCR assays at reduced stringency to facilitate detection of related but unknown organisms [12, 57, 58]. A vast number of PCR-based techniques have been developed in the past two decades and have been increasingly applied to clinical samples. For instance, multiplex PCR has been shown to increase the diagnostic yield in acute respiratory tract infections and contribute to overall improved outcome in patient care $[59,60]$. New platforms such as real-time polymerase chain reaction (rt-PCR) combine nucleic acid amplification and fluorescent detection of the amplified product in the same closed system, resulting in an excellent technique that can diagnose a wide spectrum of infectious pathogens with tremendous flexibility, rapidity, and accuracy [55, 59, 61-63]. Nucleic acid sequence analysis has become highly automated and is now practical for use in many diagnostic and reference laboratories for the identification of a large number of microorganisms, whether they are cultivatable or not. 
One particularly prevalent utility of PCR is the usage of wide-range paneubacteria $16 \mathrm{~S}$ ribosomal RNA (16S rRNA) PCR for detecting unknown bacterial organisms in tissue specimens. 16S rRNA is 1,542 nt in length and is a component of the $30 \mathrm{~S}$ subunit of prokaryotic ribosomes. The16S rRNA gene in bacteria contains wellconserved sequences that can be used as binding sites for universal PCR primers adjacent to variable sequences [64-66]. Subsequent analyses and comparisons of the sequences from amplicons to databases of known sequences can provide valuable information for etiologic diagnosis and further speciation. A set of broad-range PCR primers directed against conserved regions in the 16S rRNA gene was designed to specifically amplify either gram-positive or gram-negative bacteria [67]. These differential 16S rRNA gene PCR assays provide more specific information regarding the bacteria identity and are very useful for detecting bacterial pathogens in tissue samples in conjunction with histopathologic evaluation, special stains, and IHC.

Despite their high sensitivity, PCR techniques often face challenges from potential contamination issues. Processing of tissue samples, especially autopsy tissues, is often performed under a rather lax sterile condition and may enhance the chance of contamination. Many infectious pathogens can be present in the environment as commensals and their clinical relevance from PCR testing results can be confounded by such nature. Therefore, the PCR results should always be evaluated within the context of other diagnostic criteria. Moreover, any PCR testing of formalin-fixed tissues may be compromised by damage to DNA caused by the fixative. It is also important to know that identification to the species level may not be rigorous because the target gene may contain limited amount of sequence data available for comparison.

\section{Microarrays}

Microarrays can be performed on frozen tissue samples and may be helpful when multiplex PCR or other nucleic acid methods fail [68-70]. However, the sensitivity is generally lower than those multiplex PCR methods. Viral microarrays can be roughly divided into those targeting 10-100 agents and those designed for detection of thousands of agents, including unknown pathogens. Arrays designed to address a limited number of agents may employ multiplex consensus PCR to amplify specific genetic targets. Oligonucleotide microarrays with probes of up to $70 \mathrm{nt}$ can offer a considerable advantage for detection of rapidly evolving targets, such as RNA viruses because these arrays are less likely to be confounded by minor sequence variation. Viral microarrays can facilitate sequence analysis and pathogen identification [68, 71-73]. Additionally, both microbial and host gene targets can incorporated in these high-density arrays, thus allows an opportunity to detect microbes and assess related host responses simultaneously for pathogenic features consistent with various classes of infectious agents. 


\section{Other Advanced Techniques}

Other advanced pathology techniques such as confocal microscopy [74], proteomics [75-77], laser capture microdissection (LCM) [78, 79], and in situ PCR [80] have been used sparingly for detecting novel pathogens in a few specialized laboratories. Although they can become potentially powerful tools for diagnosis of emerging infections, most of them remain as pilot utilities and need further optimization to gain wide acceptance as mainstream techniques in practice of infectious diseases pathology.

\section{General Guidelines of Using Pathology Techniques}

Appropriate clinical specimen collection, transport, and processing are crucial to establish an accurate laboratory diagnosis of infectious diseases. Similarly, adequate tissue sampling is the first and the most important step to obtain an organism-specific diagnosis of infectious diseases by using pathology techniques. The pathology laboratory must have practical guidelines for optimal specimen collection and handling, and should communicate this information to the clinical staff and patient care sites. It is prudent to obtain biopsy or surgical samples from the precise site of infection and preferably before initiation of therapy to minimize the impact of treatment on subsequent diagnostic tests. This is particularly true for bacterial or fungal infections. Tissue specimens obtained surgically are acquired at great expense and pose considerable risk to the patient; therefore they should be procured with an amount of material adequate for both histopathologic and microbiological examination. Swabs are rarely adequate for this purpose. Representative samples from all major organs should be collected in autopsy cases, especially those unexplained fatal cases due to infectious causes.

Etiologic pathogens may be focally or sparsely present in involved organs and only a complete postmortem examination can attentively localize the causative organisms, as well as the full spectrum of their pathologic effects. In addition, the predilection site for infection may vary among different organisms. For example, herpes simplex virus tends to involve temporal lobe in the brain more frequently, while West Nile virus usually causes more severe infection in brain stem and spinal cord. Moreover, since multiple organs can be involved in the context of systemic diseases, collecting multiple representative portions of target organs with syndromebased approach (Table 45.3) and tissue samples from any other organ system with findings suggestive of infection ensures the best chance of detecting the causative agent. Influenza-associated myocarditis is a good example to show the difficulty of identifying influenza virus in the heart tissue even with prominent histopathologic changes of myocarditis, while the evidence of infection is usually present in the respiratory tissues [81]. 
Table 45.3 Tissue sample collection with syndrome-based approach

\begin{tabular}{|c|c|}
\hline Target system (syndrome) & Representative tissue sample collection \\
\hline $\begin{array}{l}\text { Central nervous system (meningitis, } \\
\text { encephalitis, myelitis) }\end{array}$ & $\begin{array}{l}\text { Cerebral cortex (frontal, parietal, temporal, and } \\
\text { occipital), brain stem (midbrain, pons, medulla), } \\
\text { spinal cord, cerebellum, basal ganglia, thalamus, } \\
\text { hypothalamus, hippocampus, and meninges }\end{array}$ \\
\hline $\begin{array}{l}\text { Respiratory system (laryngitis, } \\
\text { tracheiits, bronchitis, pneumonia, } \\
\text { pulmonary hemorrhage) }\end{array}$ & $\begin{array}{l}\text { Larynx, trachea, left and right main bronchi, hilar lung } \\
\text { with segmental bronchi, and peripheral pulmonary } \\
\text { parenchyma from both lungs }\end{array}$ \\
\hline $\begin{array}{l}\text { Cardiovascular system (myocarditis, } \\
\text { endocarditis) }\end{array}$ & $\begin{array}{l}\text { Ventricles, atrium, including endocardium, epicardium, } \\
\text { and pericardium }\end{array}$ \\
\hline $\begin{array}{l}\text { Hepatobilliary system (hepatitis, } \\
\text { cholecystitis, hepatic failure) }\end{array}$ & Different areas of liver, gall bladder \\
\hline $\begin{array}{l}\text { Gastrointestinal system (gastritis, } \\
\text { enteritis, intestinal perforation, } \\
\text { intussusception) }\end{array}$ & $\begin{array}{l}\text { Esophagus, stomach, small intestine, large intestine, } \\
\text { appendix, and mesenteric lymph nodes }\end{array}$ \\
\hline $\begin{array}{l}\text { Urinary system (nephritis, cystitis, } \\
\text { renal failure) }\end{array}$ & $\begin{array}{l}\text { Renal cortex and medulla, urinary bladder, and adrenal } \\
\text { gland }\end{array}$ \\
\hline $\begin{array}{l}\text { Reproductive system (cervicitis, } \\
\text { endometritis, pelvic inflammatory } \\
\text { diseases, funisitis, } \\
\text { chorioamnionitis) }\end{array}$ & $\begin{array}{l}\text { Cervix, uterus (endometrium and myometrium), ovary, } \\
\text { fallopian tube, umbilical cord, placenta }\end{array}$ \\
\hline $\begin{array}{l}\text { Cutaneous system (skin rashes, } \\
\text { including macule, papule, vesicle, } \\
\text { pustule, ulceration, and eschar) }\end{array}$ & $\begin{array}{l}\text { Minimally, a } 3 \mathrm{~mm} \text { punch, deep shave, or excisional } \\
\text { biopsy specimen from the representative rash lesion. } \\
\text { Multiple biopsies should be obtained if multiple } \\
\text { stages or forms of cutaneous lesions are identified }\end{array}$ \\
\hline
\end{tabular}

FFPE tissue samples are usually adequate for routine H\&E stain, special stains, IHC, and ISH assays. However, prolonged formalin fixation can cause cross-linking of proteins and nucleic acids in tissues and hence decrease the sensitivity of IHC, ISH, or PCR assays. In general, antigens and nucleic acids in tissue samples can be well preserved in paraffin-embedded blocks if formalin fixation does not exceed 2 weeks. It is highly recommended to embed tissue samples in paraffin no longer than $72 \mathrm{~h}$ after adequate formalin fixation. Although FFPE blocks can also be used for ultrastructural examination, it is preferably to dissect tissue samples into small thin pieces $\left(1 \mathrm{~mm}^{3}\right)$, placed in glutaraldehyde fixative, and stored in a refrigerator for optimal EM studies.

Sterile techniques are mandatory to obtain target tissue samples for microbiologic culture and PCR assays. While biopsy procedure is usually performed under a stringent sterile condition, autopsy is not. In addition, delay of postmortem examination will facilitate colonization by normal flora or contamination by environmental organisms and interfere subsequent diagnostic assays. Therefore, autopsy should be performed as soon as possible (preferably within $12 \mathrm{~h}$ after death) to minimize these postmortem confounding factors. Representative tissue samples for potential PCR assay should be obtained with sterile technique and frozen at $-70^{\circ} \mathrm{C}$. It is noteworthy that FFPE can also be used for PCR testing if frozen samples are not readily available, but the sensitivity is usually lower because of the chemical property of formalin fixative mentioned earlier. 


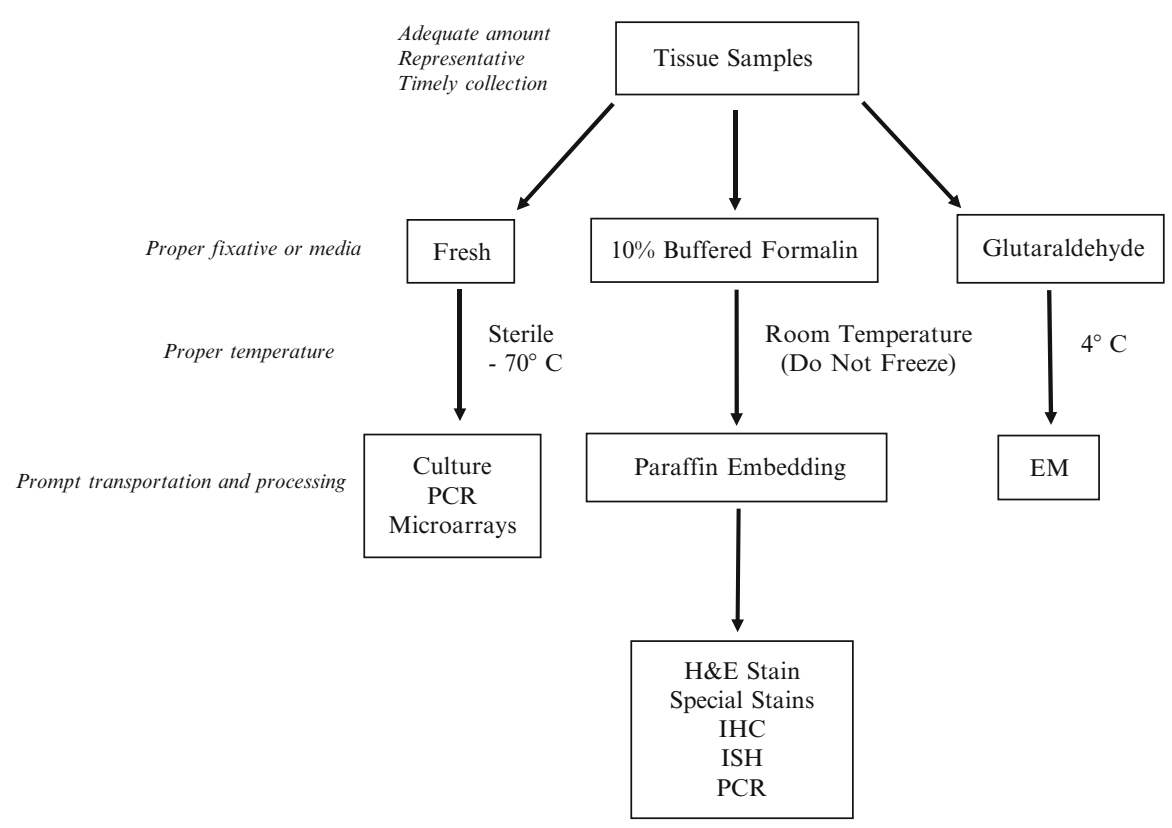

Fig. 45.3 Optimal tissue collections for pathologic studies

A diagram of optimal tissue collection for pathologic studies is shown in Fig. 45.3.

\section{Summary}

Diagnosis with pathologic techniques provides histomorphologic correlation for a specific infectious agent with the disease it causes and is essential for identifying the cause of death. It helps identify or confirm the etiology of an outbreak caused by a novel pathogen, especially from severe or fatal cases. It is crucial for management of clinical patient with unknown etiology of infection, control and prevention for emerging disease outbreak, epidemiologic surveillance, and study of pathogenesis. Tissue samples, especially postmortem specimens, should be collected adequately and promptly. They should be preserved in proper media and processed in a timely fashion. The histopathologic features identified in the tissue specimens in conjunction with relevant clinical and epidemiologic information should determine performance of specific IHC, ultrastructural, molecular, or other assays.

There are limitations of using pathologic techniques despite the advantages. Because immune mechanisms can greatly amplify the host response, the actual numbers of pathogens present in tissues can be relatively small. This means that many sections may need to be examined before a pathogen is identified. Topographic 
issues related to tissue sampling can also affect the outcome of tests. If the tissue specimens are not obtained from relevant lesions or areas with histopathologic changes, the subsequent tests performed on such specimens can all result in falsenegative outcomes. Timing of tissue sampling, as mentioned earlier, is another crucial element that can affect test results. Delayed autopsy procedure increases the chance of tissue autolysis and postmortem contamination, which can significantly interfere with histopathologic evaluation and all related pathologic tests. Technical issues, such as sensitivity and specificity, are universally present for each IHC, ISH, or PCR testing. A negative result cannot exclude the possibility of an infection caused by certain organisms because duration of illness, modalities of treatment, tissue sampling and fixation may affect the outcome of these assays. Therefore, a correlation of the test results with clinical history, epidemiological information, and other laboratory assays is highly recommended for a more accurate interpretation involving in patient care and public health management.

\section{References}

1. Schwartz DA, Bryan RT, Hughes JM (1995) Pathology and emerging infections-quo vadimus? Am J Pathol 147:1525-1533

2. Shieh W-J, Guarner J, Paddock C et al (2003) The critical role of pathology in the investigation of bioterrorism-related cutaneous anthrax. Am J Pathol 163:1901-1910

3. Walker DH, Dumler JS (1995) Will pathologists play as important a role in the future as they have in the past against the challenge of infectious diseases. Infect Agents Dis 4:167-170

4. Procop GW, Wilson M (2001) Infectious disease pathology. Clin Infect Dis 32:1589-1601

5. Zaki SR, Shieh WJ (1996) Leptospirosis associated with outbreak of acute febrile illness and pulmonary haemorrhage, Nicaragua, 1995. The Epidemic Working Group at Ministry of Health in Nicaragua. Lancet 347:535-536

6. Shieh WJ, Guarner J, Layton M et al (2000) The role of pathology in an investigation of an outbreak of West Nile encephalitis in New York, 1999. Emerg Infect Dis 6:370-372

7. Shieh W-J, Blau DM, Denison AM et al (2010) 2009 pandemic influenza A (H1N1): pathology and pathogenesis of 100 fatal cases in the United States. Am J Pathol 177:166-175

8. Guarner J, Paddock CD, Shieh W-J et al (2006) Histopathologic and immunohistochemical features of fatal influenza virus infection in children during the 2003-2004 season. Clin Infect Dis 43:132-140

9. Naber SP (1994) Molecular pathology—diagnosis of infectious disease. N Engl J Med 331:1212-1215

10. Madea B, Saukko P, Oliva A, Musshoff F (2010) Molecular pathology in forensic medicineintroduction. Forensic Sci Int 203:3-14

11. Finn WG (2007) Diagnostic pathology and laboratory medicine in the age of "omics": a paper from the 2006 William Beaumont Hospital Symposium on Molecular Pathology. J Mol Diagn 9:431-436

12. Ksiazek TG, Erdman D, Goldsmith CS et al (2003) A novel coronavirus associated with severe acute respiratory syndrome. N Engl J Med 348:1953-1966

13. Kuiken T, Fouchier RAM, Schutten M et al (2003) Newly discovered coronavirus as the primary cause of severe acute respiratory syndrome. Lancet 362:263-270

14. Berger A, Drosten C, Doerr HW, Stürmer M, Preiser W (2004) Severe acute respiratory syndrome (SARS)—paradigm of an emerging viral infection. J Clin Virol 29:13-22 
15. Franks TJ, Chong PY, Chui P et al (2003) Lung pathology of severe acute respiratory syndrome (SARS): a study of 8 autopsy cases from Singapore. Hum Pathol 34:743-748

16. Shieh W-J, Hsiao C-H, Paddock CD et al (2005) Immunohistochemical, in situ hybridization, and ultrastructural localization of SARS-associated coronavirus in lung of a fatal case of severe acute respiratory syndrome in Taiwan. Hum Pathol 36:303-309

17. Drosten C, Günther S, Preiser W et al (2003) Identification of a novel coronavirus in patients with severe acute respiratory syndrome. N Engl J Med 348:1967-1976

18. Sobrinho-Simoes M, Nesland JM, Johannessen JV (1981) Diagnostic ultrastructural pathology - sub-speciality or special stain? Diagn Histopathol 4:223-236

19. Zaki SR, Greer PW, Coffield LM et al (1995) Hantavirus pulmonary syndrome. Pathogenesis of an emerging infectious disease. Am J Pathol 146:552-579

20. Goldsmith CS, Elliott LH, Peters CJ, Zaki SR (1995) Ultrastructural characteristics of Sin Nombre virus, causative agent of hantavirus pulmonary syndrome. Arch Virol 140:2107-2122

21. Wong KT, Shieh W-J, Kumar S et al (2002) Nipah virus infection: pathology and pathogenesis of an emerging paramyxoviral zoonosis. Am J Pathol 161:2153-2167

22. Goldsmith CS, Whistler T, Rollin PE et al (2003) Elucidation of Nipah virus morphogenesis and replication using ultrastructural and molecular approaches. Virus Res 92:89-98

23. Goldsmith CS, Tatti KM, Ksiazek TG et al (2004) Ultrastructural characterization of SARS coronavirus. Emerg Infect Dis 10:320-326

24. Bayer-Garner IB (2005) Monkeypox virus: histologic, immunohistochemical and electronmicroscopic findings. J Cutan Pathol 32:28-34

25. Brandtzaeg P (1998) The increasing power of immunohistochemistry and immunocytochemistry. J Immunol Methods 216:49-67

26. Leong AS, Wright $\mathrm{J}$ (1987) The contribution of immunohistochemical staining in tumour diagnosis. Histopathology 11:1295-1305

27. Jaffer S, Bleiweiss IJ (2004) Beyond hematoxylin and eosin-the role of immunohistochemistry in surgical pathology. Cancer Invest 22:445-465

28. Sternberger LA, Hardy PH Jr, Cuculis JJ, Meyer HG (1970) The unlabeled antibody enzyme method of immunohistochemistry: preparation and properties of soluble antigen-antibody complex (horseradish peroxidase-antihorseradish peroxidase) and its use in identification of spirochetes. J Histochem Cytochem 18:315-333

29. Bosman FT, Cramer-Knijnenburg G, van Bergen Henegouw J (1980) A simplified method for the rapid preparation of peroxidase-anti peroxidase (PAP) complexes. Histochemistry 67:243-248

30. Mason DY, Sammons R (1978) Rapid preparation of peroxidase: anti-peroxidase complexes for immunocytochemical use. J Immunol Methods 20:317-324

31. Cordell JL, Falini B, Erber WN et al (1984) Immunoenzymatic labeling of monoclonal antibodies using immune complexes of alkaline phosphatase and monoclonal anti-alkaline phosphatase (APAAP complexes). J Histochem Cytochem 32:219-229

32. Jackson R, Holme ER, Phimister GM, Kennedy A, McLay AL (1990) Immunoalkaline phosphatase technique applied to paraffin wax embedded tissues in diagnostic renal pathology. J Clin Pathol 43:665-670

33. Mason DY, Sammons R (1978) Alkaline phosphatase and peroxidase for double immunoenzymatic labelling of cellular constituents. J Clin Pathol 31:454-460

34. Tao Q (1994) Double-immunostaining method using biotin-conjugated primary antibodies from the same species. J Histochem Cytochem 42:439

35. Krenacs T, Krenacs L, Raffeld M (2010) Multiple antigen immunostaining procedures. Methods Mol Biol 588:281-300

36. Wiley EL, Mulhollan TJ, Beck B, Tyndall JA, Freeman RG (1990) Polyclonal antibodies raised against Bacillus Calmette-Guerin, Mycobacterium duvalii, and Mycobacterium paratuberculosis used to detect mycobacteria in tissue with the use of immunohistochemical techniques. Am J Clin Pathol 94:307-312 
37. Carabias E, Palenque E, Serrano R, Aguado JM, Ballestin C (1998) Evaluation of an immunohistochemical test with polyclonal antibodies raised against mycobacteria used in formalinfixed tissue compared with mycobacterial specific culture. APMIS 106:385-388

38. Baisden BL, Lepidi H, Raoult D, Argani P, Yardley JH, Dumler JS (2002) Diagnosis of Wihipple disease by immunohistochemical analysis: a sensitive and specific method for the detection of Tropheryma whipplei (the Whipple bacillus) in paraffin-embedded tissue. Am J Clin Pathol 118:742-748

39. Genrich GL, Guarner J, Paddock CD et al (2007) Fatal malaria infection in travelers: novel immunohistochemical assays for the detection of Plasmodium falciparum in tissues and implications for pathogenesis. Am J Trop Med Hyg 76:251-259

40. Burt FJ, Swanepoel R, Shieh WJ et al (1997) Immunohistochemical and in situ localization of Crimean-Congo hemorrhagic fever (CCHF) virus in human tissues and implications for CCHF pathogenesis. Arch Pathol Lab Med 121:839-846

41. Zaki SR, Khan AS, Goodman RA et al (1996) Retrospective diagnosis of hantavirus pulmonary syndrome, 1978-1993: implications for emerging infectious diseases. Arch Pathol Lab Med 120:134-139

42. Webb PR, Powell L, Denyer M et al (2009) A retrospective immunohistochemical study reveals atypical scrapie has existed in the United Kingdom since at least 1987. J Vet Diagn Invest 21:826-829

43. Jin L, Lloyd RV (1997) In situ hybridization: methods and applications. J Clin Lab Anal 11:2-9

44. Werner M, Wilkens L, Aubele M, Nolte M, Zitzelsberger H, Komminoth P (1997) Interphase cytogenetics in pathology: principles, methods, and applications of fluorescence in situ hybridization (FISH). Histochem Cell Biol 108:381-390

45. Ha Y, Chae C (2009) Optimal probe size and fixation time for the detection of porcine circovirus-2 DNA by in situ hybridization in formalin-fixed, paraffin-embedded tissue. J Vet Diagn Invest 21:649-654

46. Han KH, Hollinger FB, Noonan CA, Yoffe B (1992) Simultaneous detection of HBV-specific antigens and DNA in paraffin-embedded liver tissue by immunohistochemistry and in situ hybridization using a digoxigenin-labeled probe. J Virol Methods 37:89-97

47. Aksamit AJ, Mourrain P, Sever JL, Major EO (1985) Progressive multifocal leukoencephalopathy: investigation of three cases using in situ hybridization with JC virus biotinylated DNA probe. Ann Neurol 18:490-496

48. Choi YJ (1990) In situ hybridization using a biotinylated DNA probe on formalin-fixed liver biopsies with hepatitis B virus infections: in situ hybridization superior to immunochemistry. Mod Pathol 3:343-347

49. Saglie R, Cheng L, Sadighi R (1988) Detection of Mycoplasma pneumoniae-DNA within diseased gingiva by in situ hybridization using a biotin-labeled probe. J Periodontol 59:121-123

50. Shin JH, Molitor TW (2002) Localization of porcine reproductive and respiratory syndrome virus infection in boars by in situ riboprobe hybridization. J Vet Sci 3:87-96

51. Mulder WA, van Poelwijk F, Moormann RJ et al (1997) Detection of early infection of swine vesicular disease virus in porcine cells and skin sections. A comparison of immunohistochemistry and in-situ hybridization. J Virol Methods 68:169-175

52. Tatti KM, Gentsch J, Shieh W-J et al (2002) Molecular and immunological methods to detect rotavirus in formalin-fixed tissue. J Virol Methods 105:305-319

53. Hofman V, Selva E, Landraud L et al (2003) Value of PCR amplification from formalin-fixed paraffin-embedded tissues in the diagnosis of Mycobacterium tuberculosis infection. Annales de pathologie 23:206-215

54. Bhatnagar J, Guarner J, Paddock CD et al (2007) Detection of West Nile virus in formalinfixed, paraffin-embedded human tissues by RT-PCR: a useful adjunct to conventional tissuebased diagnostic methods. J Clin Virol 38:106-111

55. Denison AM, Blau DM, Jost HA et al (2011) Diagnosis of influenza from respiratory autopsy tissues detection of virus by real-time reverse transcription-PCR in 222 cases. J Mol Diagn 13:123-128 
56. Tang YW (2009) Duplex PCR assay simultaneously detecting and differentiating Bartonella quintana, B. henselae, and Coxiella burnetii in surgical heart valve specimens. J Clin Microbiol 47:2647-2650

57. Wintermantel WM, Hladky LL (2010) Methods for detection and differentiation of existing and new crinivirus species through multiplex and degenerate primer RT-PCR. J Virol Methods 170:106-114

58. Chua KB, Bellini WJ, Rota PA et al (2000) Nipah virus: a recently emergent deadly paramyxovirus. Science (New York, NY) 288:1432-1435

59. Abdeldaim GM, Stralin K, Korsgaard J, Blomberg J, Welinder-Olsson C, Herrmann B (2010) Multiplex quantitative PCR for detection of lower respiratory tract infection and meningitis caused by Streptococcus pneumoniae, Haemophilus influenzae and Neisseria meningitidis. BMC Microbiol 10:310

60. Wang W, Ren P, Sheng J et al (2009) Simultaneous detection of respiratory viruses in children with acute respiratory infection using two different multiplex reverse transcription-PCR assays. J Virol Methods 162:40-45

61. Gadsby NJ, Hardie A, Claas EC, Templeton KE (2010) Comparison of the Luminex Respiratory Virus Panel fast assay with in-house real-time PCR for respiratory viral infection diagnosis. J Clin Microbiol 48:2213-2216

62. Agrawal AS, Sarkar M, Chakrabarti S et al (2009) Comparative evaluation of real-time PCR and conventional RT-PCR during a 2 year surveillance for influenza and respiratory syncytial virus among children with acute respiratory infections in Kolkata, India, reveals a distinct seasonality of infection. J Med Microbiol 58:1616-1622

63. Mentel R, Wegner U, Bruns R, Gurtler L (2003) Real-time PCR to improve the diagnosis of respiratory syncytial virus infection. J Med Microbiol 52:893-896

64. Weisburg WG, Barns SM, Pelletier DA, Lane DJ (1991) 16S ribosomal DNA amplification for phylogenetic study. J Bacteriol 173:697-703

65. Clarridge JE 3rd (2004) Impact of 16S rRNA gene sequence analysis for identification of bacteria on clinical microbiology and infectious diseases. Clin Microbiol Rev 17:840-862 (table of contents)

66. Greisen K, Loeffelholz M, Purohit A, Leong D (1994) PCR primers and probes for the 16S rRNA gene of most species of pathogenic bacteria, including bacteria found in cerebrospinal fluid. J Clin Microbiol 32:335-351

67. Klausegger A, Hell M, Berger A et al (1999) Gram type-specific broad-range PCR amplification for rapid detection of 62 pathogenic bacteria. J Clin Microbiol 37:464-466

68. Jabado OJ, Conlan S, Quan P-L et al (2010) Nonparametric methods for the analysis of singlecolor pathogen microarrays. BMC Bioinform 11:354

69. Kellam P (2001) Post-genomic virology: the impact of bioinformatics, microarrays and proteomics on investigating host and pathogen interactions. Rev Med Virol 11:313-329

70. Fukui S, Feizi T, Galustian C, Lawson AM, Chai W (2002) Oligosaccharide microarrays for high-throughput detection and specificity assignments of carbohydrate-protein interactions. Nat Biotechnol 20:1011-1017

71. Lipkin WI (2008) Pathogen discovery. PLoS Pathog 4:e1000002

72. Lipkin WI, Palacios G, Briese T (2009) Diagnostics and discovery in viral hemorrhagic fevers. Ann N Y Acad Sci 1171(Suppl 1):E6-E11

73. Palacios G, Druce J, Du L et al (2008) A new arenavirus in a cluster of fatal transplantassociated diseases. N Engl J Med 358:991-998

74. Pawley JB (2006) Handbook of biological confocal microscopy, 3rd edn. Springer, New York, NY

75. List EO, Berryman DE, Bower B et al (2008) The use of proteomics to study infectious diseases. Infect Disord Drug Targets 8:31-45

76. Mazzulli T, Low DE, Poutanen SM (2005) Proteomics and severe acute respiratory syndrome (SARS): emerging technology meets emerging pathogen. Clin Chem 51:6-7 
77. Ye Y, Mar E-C, Tong S et al (2010) Application of proteomics methods for pathogen discovery. J Virol Methods 163:87-95

78. Baisse B, Bian YS, Benhattar J (2000) Microdissection by exclusion and DNA extraction for multiple PCR analyses from archival tissue sections. Biotechniques 28:856-858, 860, 862

79. Xu BJ (2010) Combining laser capture microdissection and proteomics: methodologies and clinical applications. Proteomics Clin Appl 4:116-123

80. Nuovo GJ (1995) In situ PCR: protocols and applications. PCR Methods Appl 4:S151-S167

81. Nolte KB, Alakija P, Oty G et al (2000) Influenza A virus infection complicated by fatal myocarditis. Am J Forensic Med Pathol 21:375-379 